\title{
Influence of Growth Regulators on Vegetative Parameters of Gladiolus cv. Summer Sunshine
}

\author{
M.D. Manasa ${ }^{1 *}$, S.Y. Chandrashekar ${ }^{1}$, L. Hanumantharaya ${ }^{1}$, \\ M. Ganapathi ${ }^{2}$ and P. Hemanth Kumar ${ }^{3}$ \\ ${ }^{1}$ Department of FLA, ${ }^{2}$ Department of Crop Physiology, COH, Mudigere, Karnataka, India \\ ${ }^{3}$ Department of FLA, COH, Hiriyur, Karnataka, India \\ *Corresponding author
}

\begin{tabular}{|l}
\hline K e y w o r d s \\
$\mathrm{GA}_{3}, \mathrm{BA}, \mathrm{NAA}$, \\
$\begin{array}{l}\text { Thiourea and corm } \\
\text { soaking. }\end{array}$ \\
\hline Article Info \\
\hline $\begin{array}{l}\text { Accepted: } \\
\text { 12 September } 2017 \\
\text { Available Online: } \\
\text { 10 November } 2017\end{array}$
\end{tabular}

\section{Introduction}

Gladiolus (Gladiolus hybridus L.) a member of family Iridaceae, it is one of the most important bulbous ornamental crops grown in many parts of the world either as cut flower or for garden display. It is popularly known as Queen of the bulbous flowers due to its attractive shades, varying sizes of flowers, brilliant colour tones and long lasting vase life. The magnificent in florescence is also used for making bouquets and floral decorations. It has a great share in cut flower industry and fetches good premium for the money invested. It is cultivated all over the country due to its ever increasing demand of this elegant cut flower. Now a day the use of growth regulators is a common practice for modifying the developmental processes of flowers and ornamental plants. Growth regulating chemical were reporting to very effective in manipulating growth and 
flowering in gladiolus. Growth and development are to be regulated either by single or by interaction of several hormones. They play major role in directing the movement of organic metabolites and in establishing the sink. Vegetative parameters were playing an important role in all crops, which influence on photosynthesis, yield and quality of the particular crop.

\section{Materials and Methods}

The experiment was conducted at Department of Floriculture and Landscape Architecture, College of Horticulture, Mudigere (Under University of Agricultural and Horticultural sciences, Shivamogga), during 2016-17.

There were 13 treatments 3 replications, it comprising of different growth regulators viz., BA (50, 100 and 150 ppm), GA3 (50, 100 and $150 \mathrm{ppm}), \mathrm{NAA}(50,100$ and $150 \mathrm{ppm})$ and Thiourea (10000, 15000 and 20000 ppm) with control.

Medium sized corms were soaked for 24 hours in different growth regulators solution and also in water as per the treatment schedule. The soaked corms were dried under shade for 2 hours and then planted. The experiment was laid out in the Randomized Complete Block Design (RCBD) with 13 treatment and three replications.

The corms were planted at $20 \mathrm{~cm} \times 30 \mathrm{~cm}$ spacing in unit plot of $2.5 \mathrm{~m} \times 1.5 \mathrm{~m}$. The crop was fertilized with $100 \mathrm{~kg} / \mathrm{ha}$ of urea, 60 $\mathrm{kg} / \mathrm{ha}$ of MPO and $60 \mathrm{~kg} / \mathrm{ha}$ of SSP (UHS, Bagalkot), intercultural operations like weeding, earthing up and watering were done as and when necessary. The observations were recorded with respect to growth parameters at 30, 45 and 60 DAP to know the response of gladiolus to different growth regulators at different concentration.

\section{Results and Discussion}

A perusal of data revealed that days for sprouting and suckers production were varied significantly among the growth regulators treatment. Among the different growth regulators, $\mathrm{GA}_{3} @ 150$ ppm was taken minimum number of days to sprouting (9.07), on other hand control was taken maximum number of days to fifty per cent sprouting (14.13). BA @ 100 ppm was recorded maximum number of suckers per plant (4.03). Whereas, minimum number of suckers (1.00) per plant was recorded by control (Fig. 1).

Minimum number of days to sprouting might be due to free $\mathrm{GA}_{3}$, which breaking down the reserve food material by hydrolytic enzymes in presence of sufficient moisture, resulted in early sprouting of corms (Fig. 1).

Similar results were observed by Kumar and Singh (2005) and Baskaran et al., (2014) in gladiolus. Maximum number of sucker from BA treated plants might be due to BA which promotes to cell division and shoot differentiation resulting into increased number of suckers per corm (Fig. 1). These results are in conformity with Ram et al., (2001), Baskaran et al., (2014) and Khan et al., (2011) in gladiolus.

The per cent sprouting of corms were nonsignificantly varied among the treatments. However, the maximum per cent sprouting was recorded from $\left(\mathrm{T}_{3}\right) \mathrm{BA}$ @ 150 ppm (77.84) and average sprouting percentage was recorded in cultivar Summer Sunshine is 75.69 per cent (Table 1). Variation in per cent sprouting of corms was expected to occur as it was controlled by the soil characters (edaphic function). These results are in conformity with earlier reporters like Ginzburg (1973), Ram et al., (2001) in gladiolus and Sudhakar and Kumar (2012) in gladiolus. 
Table.1 Plant height and number of leaves of gladiolus cv. summer sunshine as influenced by growth regulators

\begin{tabular}{|c|c|c|c|c|}
\hline \multicolumn{2}{|r|}{ Treatment } & \multirow{2}{*}{$\begin{array}{l}\text { Sprouting } \\
\text { per cent }\end{array}$} & \multirow{2}{*}{$\begin{array}{c}\text { Plant height } \\
(\mathbf{c m})\end{array}$} & \multirow{2}{*}{$\begin{array}{l}\text { Number of } \\
\text { leaves/plant }\end{array}$} \\
\hline No. & Details & & & \\
\hline $\mathrm{T}_{1}$ & BA @ 50 ppm & 74.01 & 49.64 & 11.52 \\
\hline $\mathrm{T}_{2}$ & BA@ @ 100 ppm & 75.77 & 44.66 & 12.43 \\
\hline $\mathrm{T}_{3}$ & BA@ @150 ppm & 77.84 & 50.96 & 10.59 \\
\hline $\mathrm{T}_{4}$ & $\mathrm{GA}_{3} @ 50$ ppm & 76.60 & 68.85 & 7.96 \\
\hline $\mathrm{T}_{5}$ & $\mathrm{GA}_{3} @ 100 \mathrm{ppm}$ & 77.08 & 69.22 & 7.33 \\
\hline $\mathrm{T}_{6}$ & $\mathrm{GA}_{3} @ 150 \mathrm{ppm}$ & 75.25 & 73.52 & 8.82 \\
\hline $\mathrm{T}_{7}$ & NAA@ @ 50 ppm & 74.57 & 65.98 & 7.60 \\
\hline $\mathrm{T}_{8}$ & NAA@100 ppm & 74.61 & 64.07 & 8.51 \\
\hline $\mathrm{T}_{9}$ & NAA @ 150 ppm & 76.55 & 68.34 & 8.36 \\
\hline $\mathrm{T}_{10}$ & Thiourea@10,000 ppm & 75.51 & 70.90 & 7.17 \\
\hline $\mathrm{T}_{11}$ & Thiourea@15,000 ppm & 76.09 & 69.15 & 7.64 \\
\hline $\mathrm{T}_{12}$ & Thiourea@20,000 ppm & 77.08 & 72.47 & 8.40 \\
\hline $\mathrm{T}_{13}$ & Control & 73.07 & 59.07 & 7.09 \\
\hline & S. Em \pm & 2.17 & 1.96 & 0.52 \\
\hline & CD@ $@ 5 \%$ & NS & 5.73 & 1.52 \\
\hline
\end{tabular}

Table.2 Leaf attributes of gladiolus cv. summer sunshine as influenced by growth regulators

\begin{tabular}{|c|l|c|c|c|c|}
\hline \multicolumn{1}{|c|}{ Treatment } & $\begin{array}{c}\text { Leaf length } \\
(\mathbf{c m})\end{array}$ & $\begin{array}{c}\text { Leaf width } \\
(\mathbf{c m})\end{array}$ & $\begin{array}{c}\text { Leaf area } \\
\left(\mathbf{c m}^{\mathbf{2}}\right)\end{array}$ & $\begin{array}{c}\text { Leaf area } \\
\text { index }(\mathbf{L A I})\end{array}$ \\
\hline No. & \multicolumn{1}{|c|}{ Details } & 39.89 & 3.72 & 1578.12 & 2.63 \\
\hline $\mathrm{T}_{1}$ & BA @ $50 \mathrm{ppm}$ & 36.16 & 3.66 & 1479.85 & 2.47 \\
\hline $\mathrm{T}_{2}$ & BA @ $100 \mathrm{ppm}$ & 41.24 & 3.81 & 1425.95 & 2.38 \\
\hline $\mathrm{T}_{3}$ & BA @ $150 \mathrm{ppm}$ & 56.80 & 4.91 & 2003.24 & 3.34 \\
\hline $\mathrm{T}_{4}$ & $\mathrm{GA}_{3} @ 50 \mathrm{ppm}$ & 60.27 & 5.10 & 2004.11 & 3.34 \\
\hline $\mathrm{T}_{5}$ & $\mathrm{GA}_{3} @ 100 \mathrm{ppm}$ & 63.30 & 5.11 & 2544.12 & 4.24 \\
\hline $\mathrm{T}_{6}$ & $\mathrm{GA}_{3} @ 150 \mathrm{ppm}$ & 52.24 & 3.94 & 1389.99 & 2.32 \\
\hline $\mathrm{T}_{7}$ & NAA @ 50 ppm & 54.83 & 4.35 & 1811.78 & 3.02 \\
\hline $\mathrm{T}_{8}$ & NAA @ $100 \mathrm{ppm}$ & 57.69 & 5.07 & 2191.27 & 3.65 \\
\hline $\mathrm{T}_{9}$ & NAA @ $150 \mathrm{ppm}$ & 61.15 & 4.24 & 1661.30 & 2.77 \\
\hline $\mathrm{T}_{10}$ & Thiourea @ $10,000 \mathrm{ppm}$ & 56.20 & 4.29 & 1659.28 & 2.77 \\
\hline $\mathrm{T}_{11}$ & Thiourea @ 15,000 ppm & 62.02 & 4.88 & 2271.51 & 3.79 \\
\hline $\mathrm{T}_{12}$ & Thiourea @ 20,000 ppm & 48.70 & 4.07 & 1250.62 & 2.08 \\
\hline $\mathrm{T}_{13}$ & Control & $\mathbf{2 . 2 7}$ & $\mathbf{0 . 2 5}$ & $\mathbf{2 1 4 . 7 0}$ & $\mathbf{0 . 3 6}$ \\
\hline & S. Em \pm & $\mathbf{6 . 6 4}$ & $\mathbf{0 . 7 2}$ & $\mathbf{6 2 6 . 6 6}$ & $\mathbf{1 . 0 4}$ \\
\hline
\end{tabular}


Fig.1 Sprouting and suckering behavior of gladiolus cv. summer sunshine as influenced by growth regulators

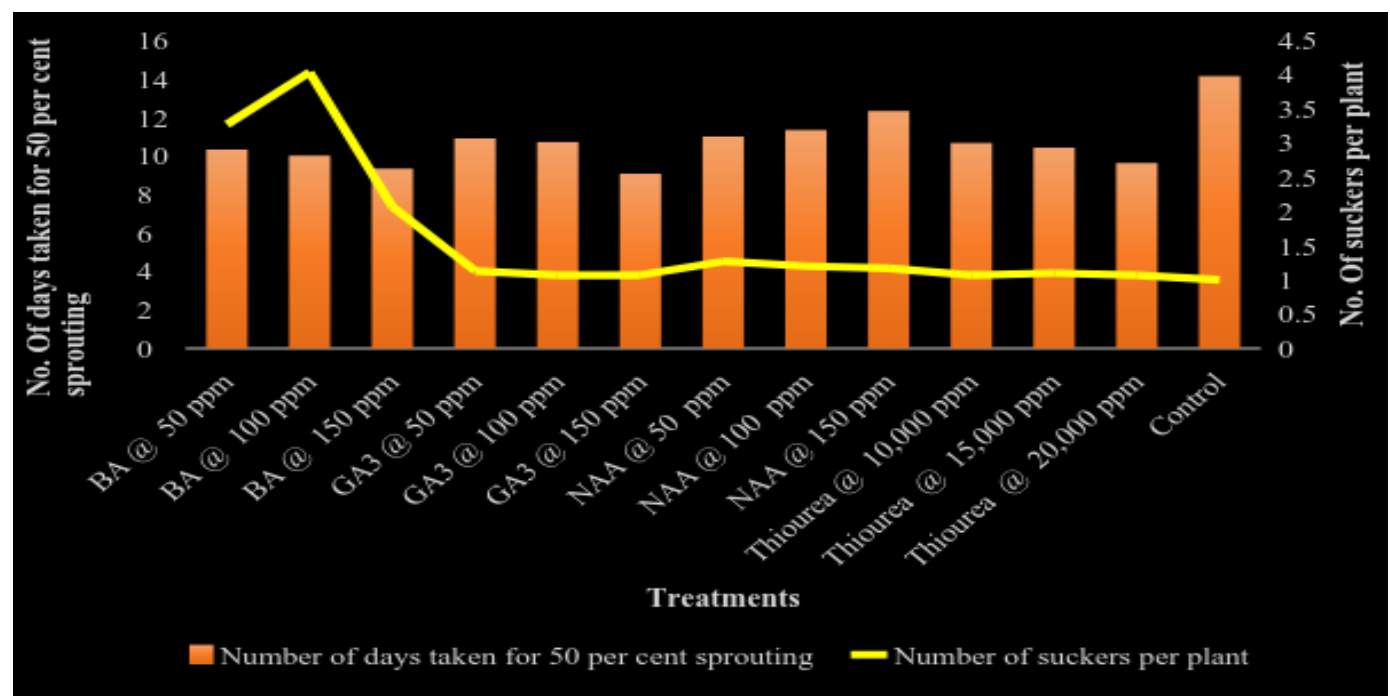

The maximum plant height $(73.52 \mathrm{~cm})$ was recorded from treatment $\mathrm{GA}_{3} @ 150 \mathrm{ppm}$. Whereas minimum plant height $(44.66 \mathrm{~cm})$ was recorded from BA @ 100 ppm (Table 1). Maximum number of leaves (12.43) per plant was recorded from BA @ 100 ppm, whereas minimum number pf leaves per plant (7.09) was recorded from control. The maximum plant height from $\mathrm{GA}_{3} @ 150$ ppm, might be due to rapid cell division and cell elongation at internodal region, which resulted in more number of cells and increase in cell length as reported by Greulach and Haesloop (1958). The minimum plant height with application of BA might be due to counteracting the apical dominance by encouraging the lateral branching (Table 1) and same treatment records maximum number of leaves per plant might be due to number of suckers per plant. Similar results have been reported by Gaur et al., (2003), Kumar et al., (2008), Ranaet al., (2005) and Sharma et al., (2004) in gladiolus.

Maximum leaf length $(63.30 \mathrm{~cm})$, leaf width $(5.11 \mathrm{~cm})$, leaf area $\left(2544.12 \mathrm{~cm}^{2}\right)$, leaf area index (4.24) was recorded from treatment $\mathrm{GA}_{3} @ 150$ ppm. Whereas, minimum leaf length $(36.16 \mathrm{~cm})$ and leaf width $(3.66 \mathrm{~cm})$ were recorded from BA @ 100 ppm (Table 2). Minimum leaf area $\left(1250.62 \mathrm{~cm}^{2}\right)$ and leaf area index (2.08) was recorded from control.

Maximum leaf length, leaf width, leaf area and leaf are index was recorded from $\mathrm{GA}_{3} @$ $150 \mathrm{ppm}$, thismight be due to rapid cell division and cell elongation at internodal region, which resulted in more number of cells and increase in cell length. The minimum leaf length and leaf width with application of BA might be due to counteracting the apical dominance and cell elongation by encouraging the lateral branching/cell differentiation (Table 2). Minimum leaf area and leaf area index from control might be due to less number of leaves. Similar results have been reported by Patel et al., (2013), Rana et al., (2005) and Sharma et al., (2004) in gladiolus.

Application of plant growth regulators as perplant corm soaking play an important role in expression of vegetative attributes in a significant way, from the experiment it can be conclude that $\mathrm{GA}_{3}$ may encourage to increase the plant height, leaf length and width, which provides more surface area for photosynthesis 
and resulted to more rate of photosynthesis assimilation, whereas BA resulted to cell differentiation, which may encourage to more number of corms production in further developmental stage of the corp.

\section{References}

Anonymous, 2013, Package of Practices. Univ. Hort. Sci., Bagalkot, Karnataka, India, pp. 204-205.

Baskaran, V., K. Abirami and S. D. Roy., 2014. Effect of plant growth regulators on yield and quality in gladiolus under Bay Island conditions. J. Hortic. Sci., 9(2): 213-216.

Gaur, G. S., Chaudhary, T. C. And J. D. Trivedi., 2003. Effect of $\mathrm{GA}_{3}$ and IAA on growth, flowering and corm production in gladiolus cv. Eurovision. Farm Science Journal, 12(1): 1-3.

Ginzburg, C., 1973, Harmonal regulation of cormel dormancy in Gladiolus grandiflorus. Journal of Experimental Botany, 24: 558-566.

Greulach, V. A. And J. C. Haeshloop., 1958. The influence of $\mathrm{GA}_{3}$ on cell division and cell elongation in Phaseolus vulgaris. American J. Botech., 45: 568570.

Khan, F. N., Rahman, M. Hossain M.M. and T. Hossain., 2011.Effect of benzyladenine and gibberellic acid on dormancy breaking and growth in Gladiolus cormels. Thai J. Agric. Sci., 44(3): 165-174.

Kumar, P. S., R.. Bhagawati, R. Kumar and T. Ronya., 2008. Effect of plant growth regulators on vegetative growth, flowering and corm production of gladiolus in Arunachal Pradesh. J. Orn. Hort., 11(4): 265-270.

Kumar, V. And R. P. Singh 2005. Effect of soaking of mother corms with plant growth regulators on vegetative growth, flowering and corm production in gladiolus. J. Orn. Hort., 8(4): 306-308.

Patel, B. B., J. R. Desai, G. D. Patel and H. F. Patel., 2013. Influence of foliar application of nitrogen and plant growth regulators on growth, flowering and corm production of gladiolus cv. American beauty. BIOINFOLET - J. Life Sci., 10(2): 415-417.

Ram, R., D. Mukherjee and S. Manuja., 2001. Plant growth regulators affect the development of both corms and cormels in Gladiolus. Hort. Sci., 37(2):343-344.

Rana, P., J. Kumar and M. Kumar., 2005. Response of $\mathrm{GA}_{3}$, plant spacing and planting depth on growth, flowering and corm production in Gladiolus. J. Orn. Hort., 8(1): 41-44.

Sharma, J. R., R. B. Gupta and R. D. Panwar., 2004. Growth flowering and corm production Gladiolus cv. Friendship as influenced by foliar application of nutrients and growth regulators. J. Orn. Hort., 7(4): 154-158.

Sudhakar, M. And S. R. Kumar, 2012. Effect on corm size and growth regulators on growth and flowering of Gladiolus cv. White Friendship. Indian J. Plant Sci., 1(3): 133-136.

\section{How to cite this article:}

Manasa, M.D., S.Y. Chandrashekar, L. Hanumantharaya, M. Ganapathi and Hemanth Kumar, P. 2017. Influence of Growth Regulators on Vegetative Parameters of Gladiolus cv. Summer Sunshine. Int.J.Curr.Microbiol.App.Sci. 6(11): 1299-1303. doi: https://doi.org/10.20546/ijcmas.2017.611.155 